\title{
Lukutaitotutkimuksen käsitekartta
}

MIKKO PERKIÖ

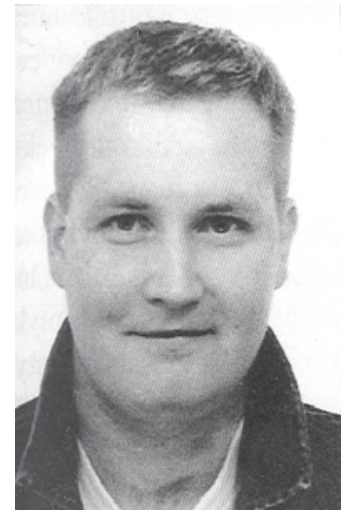

L

ukutaito on tärkein oppimisen ja opiskelun edellytys. Lukutaidon merkitys on korostunut, kun informaation määrä ja merkitys ovat kasvaneet. Lukutaito ymmärretään nykyään yhä monimuotoisemmaksi taidoksi, jolla on informaatioyhteiskunnassa yhteyksiä talouteen, kansalaisten osallisuuteen ja työelämän muutokseen. Kehitysmaissa lukutaidolla on keskeinen paikka keskustelussa koulutuksesta, jota esitetään ratkaisuksi kestävään kehitykseen (Perkiö 2007). Samoin lukutaito voisi olla tärkeä elementti, kun valjastetaan suomalaista koulutusosaamista globaalin tasa-arvon palvelukseen.

Tämä artikkeli on kirjallisuuskatsaus, joka jäsentää lukutaitotutkimuksen tärkeimpiä käsitteitä ja tutkimussuuntauksia. Jäsennys purkaa lukutaidon käsitettä nykyistä paremmin hahmotettaviin osiin. Artikkelin avulla lukutaidon käsitettä on nykyistä helpompi käyttää koulutuksen yhteiskunnallisen merkityksen tutkimuksessa esimerkiksi kansalaisuuden tai kestävän kehityksen yhteydessä.

Lukutaito on ollut kansainvälisen huomion kohteena 1950-luvulta. Vuonna 1947 perustetulle YK:n kulttuurijärjestö Unescolle tuli yhdeksi tehtäväksi peruskoulutukseen oleellisesti liittyvän lukutaidon edistäminen (Takala 2001, 7). Luku- ja kirjoitustaidoista puhutaan useimmiten kahdessa yhteydessä. Ensinnäkin lapsen kehitystä arvioidaan usein sen kautta, osaako hän lukea ja kirjoittaa. Toiseksi puhutaan aikuisten luku- ja kirjoitustaidosta (adult literacy). Tämä artikkeli tarkastelee aikuislukutaitoa, josta käytän jatkossa lyhyttä muotoa lukutaito.

Lukutaitotutkimuksen voi jakaa näkökulmiin, joissa lukutaito nähdään 1) kykynä, 2) yksilön elämän osasena, 3) sosiaalisena käytäntönä ja 4) kriittisen tulkinnan prosessina (Lytle \& Wolfe 1989). Syvennän tätä nelijakoa ja tuon siihen lisänä tietoyhteiskunnan lukutaidot. Käyn läpi kuusi erilaista tapaa käyttää lukutaidon käsitettä. Tarkastelen 1) lukutaitoisuusastetta ja 2) lukutaidon osaamistasoa, joissa on molemmissa kvantitatiivinen painotus. 3) Funktionaalinen lukutaito ja tunnetun pedagogi Paolo Freiren mukaan nimetty 4) freireläinen käsitys korostavat lukutaidon suhdetta tarkasteltavaan yhteisöön. 5) Sosiokulttuurinen lähestymistapa painottaa vielä edellä mainittuja enemmän lukutaidon kontekstisidonnaisuutta. 6) Informaatioyhteiskunnan yhteydessä tarvittavat lukutaidot tuovat keskusteluun jälleen uuden tason.

Tarkastelen eniten käytettyihin lukutaidon viitekehyksiin liittyviä tyypillisiä lukutaidon määritelmiä kahden ulottuvuuden kautta. Ensinnäkin arvioin sitä, miten moniulotteisena ilmiönä luku- 
taito ymmärretään. Toiseksi pohdin sitä, missä määrin lukutaitoa pidetään yleisenä ja missä määrin paikallisena, tilannesidonnaisena ilmiönä. Kommentoin sitä, miten lukutaitokäsitykset limittyvät toinen toisiinsa. Tarkastelen myös käsitteisiin liittyviä etuja ja ongelmia. Lopuksi muodostan lukutaidon viitekehyksistä kaksi käsitekarttaa, jotka antavat aiheesta kokonaiskuvan.

Tämä käsitteellinen poikkileikkaus on ollut samalla lukemis- ja tutkimusprosessi. Se on nostanut esiin kaksi keskeisintä ulottuvuutta, joihin lukutaidosta puhujan on hyvä suunnata huomiota (ks. käsitekartta s. 18). Artikkeli voittaa kokonaiskuvan kirkastamisessa enemmän kuin menettää siinä, että valitut lähestymistavat eivät ole täysin yhteismitallisia. Esimerkiksi lukutaitoisuusastetta voisi pitää vain pinnallisena mittausvälineenä. Mutta koska tätä käsitettä yhä käytetään huomattavasti kansainvälisissä järjestöissä, mediassa ja joissakin laadukkaissa tutkimuksissa, sitä kannattaa tarkastella myös tutkimuksellisena viitekehyksenä. Sosiokulttuurisen lähestymistavan ja informaatioyhteiskunnan lukutaidon osalta päästään vain alustavaan analyysiin näistä vivahteikkaista ja laajoista viitekehyksistä.

\section{Lukutaitoisuusaste}

Lukutaidon kaksiulotteinen kyllä/ei-arviointi on varhaisin tapa tarkastella lukutaitoa. Länsi- ja Pohjois-Euroopan maiden, mm. Ruotsin (edelläkävijä koko väestön lukutaidossa) ja Yhdysvaltojen avioliittorekistereissä, sotaväenrekrytoinneissa ja väestölaskennoissa on satunnaisia tietoja väestön lukutaidosta jo 1500-luvulta Euroopassa ja tätä systemaattisemmin 1800-luvulta alkaen (Cipolla 1969, 113-130; Graff 1981). Unescon yleiskokouksessa 1958 hyväksytyn ja yleisimmän edelleen sovellettavan määritelmän mukaan lukutaitoisiksi aikuisiksi lasketaan ne yli 15-vuotiaat, jotka osaavat lukea ja kirjoittaa jokapäiväistä elämäänsä koskevan lauseen. Pohdinta lukutaitoisuuden kriteereistä on jatkunut puoli vuosisataa. Esimerkiksi Yhdysvallat, Iso-Britannia ja Maailmanpankki määrittelevät lukutaidon peruskyvyiksi, jotka kattavat lukemisen, kirjoittamisen ja laskemisen. Unescon (2006a) raportti viittaa lukutaidon määritelmän yhteydessä myös suullisiin taitoihin. Tämä laajentaa määritelmää entisestään. (Ks. Raassina 1990, 20; Unesco 1957, 18-34; 2006a, 149-152.)

Unescon (1957, 13-15) ensimmäinen laaja lukutaitotutkimus arvioi, että 1900-luvun puolivälissä
43-45 prosenttia maailman aikuisväestöstä oli lukutaidottomia. Unescon (2006a, 63-66) viimeisimmässä "Education for All” -lukutaitoraportissa lukutaidottomien osuus on enää noin 18 prosenttia aikuisväestöstä. Kuitenkin köyhimmissä Afrikan maissa vain vajaa 20 prosenttia aikuisista osaa lukea ja kirjoittaa. Sen sijaan tällä tavoin mitattuna teollistuneissa maissa käytännössä lähes kaikki ovat lukutaitoisia.

Edellä käsitelty Unescon ja valtioiden omaksuma määritelmä on yleisin tapa mieltää lukutaito. Lukutaitomittaukset perustuvat kognitiiviseen käsitykseen, jonka mukaan lukutaito - lukeminen, kirjoittaminen ja laskeminen - on joukko kontekstista riippumattomia opittavia taitoja (Unesco 2006a, 149). Monet tärkeät lukutaitotutkijat kytkevät lukutaidon ja kirjoituksen tiivisti toisiinsa (Ong 1982; Olson 1994; Goody 2000). Tämän näkemyksen kriitikot esitellään sosiokulttuurisen lähestymistavan yhteydessä.

Lukutaitoisuusaste mittaa niiden aikuisten väestöosuutta kaikista aikuisista, jotka osaavat lukea ja kirjoittaa yksinkertaisen lauseen. Se on hyvin karkea mittari väestön informaation käsittelytaidolle, mutta sitä on yksinkertaisuutensa ja suhteellisen neutraaliutensa vuoksi käytetty kansainvälisessä vertailussa. Intian eteläisimmän osavaltion Keralan ja Suomen vertailu osoitti, kuinka sukupuolten välinen tasa-arvo ja korkea lukutaitoisuusaste yhdistyvät sosiaalisen kehityksen avaimeksi sekä pitkälle kehittyneessä tietoyhteiskunnassa että matalan tulotason maassa (Ross 2006).

Lukutaitoisuusasteen käyttöön liittyy ongelmia, jotka koskevat siihen pohjautuvan tiedon universaalisuutta, perusteellisuutta ja luotettavuutta. Käsittelen tässä yhteydessä luotettavuutta. Pohdin tuonnempana muita lukutaitoisuusasteeseen liittyviä ongelmia.

Lukutaitotilastojen luotettavuutta vähentää ensinnäkin se, että lukutaidon määritelmät vaihtelevat eri maiden ja eri väestölaskentojen välillä. Esimerkiksi viidessä Pakistanin väestölaskennassa oli kaikissa käytössä erilainen lukutaidon määritelmä. Myös aikuisväestön määritelmän ikäraja vaihtelee maiden välillä. Jotkut maat viittaavat lukutaidon määritelmässään esimerkiksi sanomalehden lukemiseen, kun taas toiset maat käyttävät mittarina kouluvuosia, jotka ovat koulutuksen tasoerojen vuoksi ongelmallisia likiarvoja. Lisäksi lukutaitoa koskevia tietoja puuttuu. Laajan lukutaidottomuuden maissa on vasta hiljattain alettu 
kerätä tietoa lukutaidosta. Korkean lukutaitoisuusasteen maissa tarkastellaan lukutaitoa sen osaamistasoon kohdistuvilla arvioinneilla, ei lukutaitoisuusasteen avulla. (Unesco 2006a, 156-162.)

Viime vuosiin saakka kaikki kansainväliset lukutaitomittaukset ovat perustuneet virallisiin väestölaskennassa saatuihin tietoihin. Väestöviranomaisen arvio henkilön lukutaitoisuudesta on voinut perustua henkilön omaan ilmoitukseen, kolmannen osapuolen eli tavallisesti "perheenpään” tekemään arvioon tai kouluvuosien määrään perustuvaan likiarvoon. Viimeisen viiden vuoden aikana lukutaitotilastot ovat alkaneet perustua yhä laajemmin käyntitestaukseen. Tämä kotona tehtävä suora mittaus tuottaa objektiivista tietoa henkilön lukutaidon tasosta. (Unesco 2006a, 163.) Käyntitestauksen käyttöönotto on paljastunut, että väestölaskennoissa käytettävät epäsuorat lukutaitoisuuden arviointimenetelmät kohottavat lähes aina maan lukutaitoisuusasteen todellista korkeammaksi (Schaffner 2005).

\section{Funktionaalinen lukutaito}

Unesco $(1957,179)$ oli havainnut, että lukutaitoa saattoi hyödyntää nimenomaan kaupunkimaisissa yhteiskunnissa. Funktionaalisuuden käsitteellä huomio haluttiin kiinnittää siihen, että erilaisissa kulttuureissa, yhteiskunnissa ja yhteisöissä tarvittiin kussakin omanlaistaan lukutaitoa. Funktionaalisen lukutaidon käsitteellä uskottiin voitavan vastata niihin modernisoituvien yhteiskuntien kysymyksiin, joiden analyysiin mekaaninen lukutaitoisuusaste ei yksinkertaisuutensa vuoksi pystynyt. Puhe lukutaidon funktionaalisuudesta oli ensimmäinen kritiikki lukutaitoon liitettyä universaalisuutta kohtaan. (Gray 1956; Verhoeven 1994)

1960- ja 1970-luvuilla funktionaalinen lukutaitokäsitys liitti lukutaitoa talouskasvuun ja kansakunnan kehitykseen. Tuolloin nousi esille myös näkemys lukutaidosta yhteiskunnallisena muutosvoimana. Funktionaalisen lukutaidon käsitettä on vaivannut vakiintumattomuus ja epäselvyys. Lisäksi funktionaalisuudelle annettu sisältö on voitu liittää keskenään ristiriitaisiin tavoitteisiin tai tarpeisiin. Yhtäällä on huomioitu taloutta ja tuottavuutta tai toisaalla on korostettu osallisuuden ja tietoisuuden edistämistä. (ks. Gray 1956; Unesco 1973; Verhoeven 1994; Raassina 1990, 19-57.) Unescon yleiskokous omaksui 1978 nykyisinkin funktionaalisesta lukutaidosta käytettävän määritelmän: henkilö on funktionaalisesti lukutaitoinen, kun hän voi osallistua yhteisössään kaikkiin lukutaitoa edellyttäviin toimintoihin ja kun hän kykenee lukemaan, kirjoittamaan ja laskemaan kehittääkseen itseään ja yhteisöään (Unesco 2005).

Soili Paananen (2006) käyttää funktionaalisen lukutaidon käsitettä väitöskirjassaan, jossa hän tarkastelee dysleksiaa eli lukemisen ja kirjoittamisen vaikeutta osana aikuisten elämänkertoja. Dysleksiaa esiintyy 5-18 prosenttia maailman aikuisista. Tämä lukutaitovaikeus on informaatioyhteiskunnassa syrjäytymisriski, jota voidaan pienentää yksilöllisellä oppijan elämänkertaan kytkeytyvällä kielellisellä harjoittelulla. (Paananen 2005.) Funktionaalinen lukutaito sopii myös viitekehykseksi siihen kulttuuriseen uudelleen oppimisen prosessiin, jonka maahanmuuttaja kohtaa uudessa maassa. Funktionaalisuuden ajatus on taustalla myös lukutaidon osaamistason mittaamisessa.

\section{Lukutaidon osaamistaso}

Lukutaitoisuusaste ei tarjoa riittävän perusteellista tietoa lukutaidon osaamistasoon liittyvästä suuresta vaihtelusta yhteiskuntien sisällä ja eri maiden välillä. Määritelmiin ja mittaukseen liittyvien epävarmuuksien lisäksi on ongelmallista, että lukutaitoisuusasteessa alkeelliset ja pitkälle kehittyneet lukutaidot tulevat luokitelluksi vain yhdellä termillä "lukutaitoinen”.

Kansainvälinen koulutuksen vaikuttavuuden arvioinnin järjestö IEA (International Association for the Evaluation of Educational Achievement) on arvioinut koululaisten lukutaidon osaamistasoa jo 1960 -luvulta lähtien. Thorndike (1973) totesi 15 maan vertailututkimuksessa teollisuusmaiden ja kehitysmaiden väliset luetun ymmärtämisen erot erittäin suuriksi. Tätä IEA:n alulle laittamaa lähestymistapaa edustaa OECD:n vuodesta 2000 toteuttama 15-vuotiaiden koululaisten kansainvälinen arviointiohjelma PISA (Programme for International Student Assessment), jossa Suomen koululaiset ovat menestyneet erinomaisesti (OECD 2008). Aikuislukutaitovertailut ovat jatkoa koululaisiin kohdistetuille vertailututkimuksille.

Vuosina 1994-1998 toteutettiin 20 OECD-maan (väestöt ovat ns. täysin lukutaitoisia tai hyvin lähellä sitä) survey-tutkimus, jossa lukutaito määriteltiin kykynä käsitellä painettua informaatiota jokapäiväisissä toimissa kotona, työssä ja vapaaajalla omien tavoitteiden saavuttamiseksi ja itsensä kehittämiseksi. Lukutaitotestit kartoittivat osaamista kolmella osa-alueella, jotka ovat asiatekstien 
lukutaito, dokumenttien käyttötaito ja peruslaskutoimitusten hallinta luetun tekstin yhteydessä. Tutkimus tarkasteli lukutaitoa jatkumona, joka luokiteltiin viidelle tasolle. Taso 1 tarkoittaa niin heikkoa lukutaitoa, että esimerkiksi ohjeen lukija saattaisi antaa väärän annoksen lääkettä lapselle. Tasolla 2 lukija ymmärtää yksinkertaista tekstiä. Tasoa 3 pidetään riittävänä selviytymiseen modernissa kaupunkimaisessa yhteiskunnassa. Tasot 45 osoittavat edellistä korkeampitasoisia tiedonkäsittelytaitoja. (OECD \& Statistics Canada 2000; Linnakylä \& Malin \& Blomqvist \& Sulkunen 2000.)

Huomattavalla osalla länsimaista aikuisväestöä lukutaito on vaatimatonta tasoa. Iso-Britanniassa yli puolella sekä Yhdysvalloissa ja Kanadassa yli 40 prosentilla väestöstä lukutaito jäi viisiportaisella asteikolla tasoille 1-2. Tutkimuksen maista heikointa lukutaito on itäisen Euroopan maissa ja Chilessä, joissa yli kaksi kolmasosaa jäi heikolle tasolle (1-2). Ruotsissa on vertailumaista paras lukutaito. Siellä vain joka neljännen lukutaito on tasoa 1 tai 2. Pohjoismaissa on kaiken kaikkiaan paras lukutaito ja väestön tasoerot ovat pieniä. Yhdysvalloissa ja Iso-Britanniassa tasoerot olivat suurimmat. (OECD \& Statistics Canada 2000.)

Edellä käsitellyssä OECD-vertailussa suomalaisten aikuisten lukutaito oli keskimäärin korkeatasoinen, mutta heikotkin lukijat arvioivat lukutaitonsa hyväksi. Ikäluokkien väliset taitoerot olivat suuret; nuorimmat ikäluokat lukivat parhaiten. Työ ja etenkin tietotyö parantavat lukutaitoa, silti lukutaito kehittyy myös vapaa-ajalla. Sukupuolierot olivat Suomessa aikuisten (toisin kuin lasten ja nuorten) kohdalla vähäiset. Lukutaidolla oli yhteys työllistymiseen ja työssä menestymiseen. Heikoimmin menestynyt kolmannes osaa kyllä perinteisessä mielessä lukea, mutta heidän osaamisensa ei täytä tietoyhteiskunnan vaatimuksia. Heikoimmalle tasolle 1 jäi kymmenesosa, mikä vastaa Paanasen $(2006,56)$ arvioita vakavia lukutaitovaikeuksia omaavien määrästä. (Linnakylä ym. 2000.)

Maan lukutaitoprosentin ja maan koulutustason välillä on selkeä yhteys (Unesco 2006a, 173174). Toisaalta äidin lukutaidon osaamistason, ei niinkään koulutusajan, merkityksestä äitien terveyskäyttäytymiselle on näyttöä Nepalissa ja Venezuelassa tehdyissä tutkimuksista (LeVine \& LeVine \& Rove \& Schnell-Anzola 2004; Schnell-Anzola \& Rove \& LeVine 2005). Myös tulos lukutaitotestissä ennustaa paremmin talouskasvua kuin kouluvuosien käyttäminen mittarina. Samoin lukutaidon osaamistasoilla ja väestöryhmien luku- taitoon liittyvällä tasa-arvolla voidaan selittää merkittävästi taloudellisen kasvun vaihtelua teollisuusmaissa vuosina 1960-1994. (Coulombe \& Tremblay \& Marchand 2004.)

Koko maailman aikuisväestön mittausepävarmuuksista kärsivän lukutaitoasteen (82 \%) (Unesco 2006a, 63) rinnalla on tärkeää tarkastella maailman lukutaidon osaamistasoa. Karkean hahmotelman mukaan yli puolet maailman aikuisväestöstä on joko lukutaidottomia tai heidän lukutaitonsa on tasolla 1. Voidaan myös arvioida, että maailman aikuisväestöstä vain noin yksi kymmenesosa osaa lukea kaupunkimaisen mittapuun mukaan hyvin eli heidän lukutaitonsa on tasoa 3-5. Tosin reilut puolet maailman väestöstä asuu kaupungeissa ja vajaa puolet maaseudulla. Vaikka kaikki maailman lukutaitoiset asuisivat kaupungeissa, silti vain yhdellä viidestä olisi hyvä lukutaito.

Kanadan tilastokeskuksen tutkimus jatkaa kehittyneiden maiden vertailua. ALL-tutkimus (adult literacy and lifeskills) sisältää monipuolista tietoa lukutaidon suhteesta terveyteen, perhetaustaan ja työmarkkinoihin. (Statistics Canada 2005.) Tämän tutkimuksen menetelmistä on kirjoitettu toinen teos, jossa tarkastellaan mm. tiimityötä ja tietotekniikka (Murray \& Clermont \& Binkley 2005).

Unescossa valmisteilla oleva arviointiohjelma Literacy Assesment and Monitoring Programme (LAMP) pohjautuu em. vertailujen käsitteistöön ja 5-portaiseen tasoluokitukseen. Ohjelman aikoo kuvata koko lukutaitoisuuden kirjon maailmassa. Tutkimus pyrkii tilastolliseen edustavuuteen. Koulutettujen haastattelijoiden avulla taataan tutkimuksen laatua. Funktionaalisuutta huomioidaan sillä, että testimateriaali laaditaan Unescon ja kunkin maan välisenä yhteistyönä. (Unesco 2006a, 185; 2006b.) Yhteiskuntien, kielten ja vähemmistöjen välisten erojen ja moninaisuuden huomioiminen tekee maiden vertailemisesta LAMP-ohjelmassa haastavaa (ks. Unesco 2007, 2-9).

Sosio-kulttuurisen viitekehyksen tutkijat ovat kritisoineet kansainvälistä lukutaitovertailua siitä, että se perustuu ajatukselle yhtenäisestä ylikansallisesta kulttuurista. Heidän mukaansa testielementit ovat aina tutumpia joidenkin maiden asukkaille kuin toisten maiden, ja tämä vääristää tuloksia. (Hamilton \& Barton 2000.) OECD-maiden välillä on kuitenkin kulttuurista yhtäläisyyttä siinä määrin, että tutkimuksen toteutuksessa on mieltä. Kuitenkin LAMP-ohjelman yhteydessä on syytä kysyä, minkälaisiksi moderniin yhteiskuntaan sopivat kysymykset tulisi muuttaa, kun niiden avul- 
la testataan omavaraistalouteen perustuvan kulttuurin jäseniä.

\section{Freireläinen näkökulma}

Freireläinen lukutaitotulkinta on nimetty brasilialaisen kasvatussosiologi Paolo Freiren mukaan. Hänen klassikkonsa Sorrettujen pedagogiikka (1972, suom. 2005) korostaa lukutaidon ja kollektiivisen oppimisen merkitystä yhteiskunnallisen oikeudenmukaisuuden toteuttamissa. Freireläisessä pedagogiikassa köyhimpien kansanosien ihmiset oppivat lukutaitoa, kun he työstävät omaan arkeensa liittyviä käsitteitä dialogissa opettajan kanssa. (Freire 1987; 2001.) Lukutaidon merkitys syntyy siitä, että maailmassa oleminen toteutuu kielen avulla tehtävien uusien tulkintojen välityksellä (Freire \& Makado 1987).

Freiren tapaan Gran (1983) näkee olennaisena massojen tietoiseksi tulemisen. Tietoiset ja aktiiviset kansalaiset voivat ymmärtää ympäröivää todellisuutta ja muuttaa sitä (ks. Hannula 2000). Gran uskoi yhteiskunnallisen kehityksen olevan mahdollista vasta, kun massoista tulee riittävän vahvoja painostamaan vallassa olevia. Freireläinen lukutaito liittyy ajankohtaiseen keskusteluun kriittisestä pedagogiikasta (ks. Kiilakoski \& Tomperi \& Vuorikoski 2005; Suoranta 2005).

Auerbach (2005) puolestaan osoittaa Freiren näkemystä kohtaan kriittisellä käsitteellään pedagogy of not-literacy sen, kuinka käytännön ongelmiin keskittyvät ruohonjuuritason liikkeet voivat tuottaa sivutuotteena lukutaitojen oppimista. Yhteistä Freiren ja Auerbachin käsityksille on ihmisten oman toimijuuden korostaminen ja lukutaidon oppiminen yhteydessä arjen asioihin.

Freiren näkemykset saavat tukea mm. Unescon raportilta (2006a, 139), joka esittelee useita esimerkkejä siitä, kuinka koulutustason ja siten lukutaidon nousulla on myönteinen suhde poliittiseen osallistumiseen. Korkeammin koulutetut äänestävät useammin ja heillä on suvaitsevammat asenteet. He kannattavat demokratiaa. (Ks. myös Hannum \& Buchman 2003, 17-20.) Esimerkiksi nepalilaisten naisten yhteiskunnallinen osallistuminen on vahvasti yhteydessä siihen, kuinka intensiivisesti naiset osallistuvat aikuislukutaito-ohjelmaan (Burchfield \& Hua \& Baral \& Rocha 2002). Freireläinen lukutaitokäsitys voi tehdä lukutaitokampanjoista (esim. Arnove \& Graff 1987) ja -ohjelmista kohderyhmien silmissä hyväksyttäviä, koska freireläinen lukutaitokäsitys on konkreettinen ja op- pijalähtöinen. Lisäksi se antaa äänen syrjässä oleville yksilöille ja yhteisöille.

\section{Sosiokulttuurinen lähestymistapa}

Sosiokulttuurisen lukutaitotutkimuksen pioneeri Richard Hoggart (1957) oli huomattavasti aikaansa edellä, kun hän tarkasteli lukutaitoa osana arkielämää ja populaarikulttuurin käyttöä. Varsinkin 1980-luvulta alkaen tutkijat (mm. Street 1984; Gee 1990; Collins 1995) ovat osoittaneet, että lukutaito on paljon aiemmin esitettyä moninaisempi ilmiö. Tämän vuoksi lukutaidosta puhutaan nykyisin usein monikossa. Graff (1979) peräänkuulutti, että lukutaitoa on tarkasteltava täsmällisissä historiallisissa ja sosiaalisissa konteksteissa. Käsitteellään lukutaitomyytti hän viittasi siihen, että lukutaidosta on tehty liian kaikkivoipa ja yksioikoinen selittäjä sosiaaliselle muutokselle.

Street (1984, 19-125; 2001, 7-10) on kritisoinut sellaista lukutaitokäsitystä, joka ei kiinnitä huomiota sosiaaliseen kontekstiin tai joka yksinkertaistaa lukutaidon roolia suhteessa suulliseen kulttuuriin. Hän on nimennyt tämän lähestymistavan autonomiseksi malliksi, jonka hän liittää arvostelemiinsa tutkimuksiin (esim. Goody 1968; Ong 1982). Autonomisen käsityksen vastakohtana on ideologinen malli, joka on tietoinen lukutaitoon liittyvästä kontekstista ja valta-asetelmasta sekä toimijan omasta roolista lukutaidon määrittelyssä.

Sosiokulttuurisen lähestymistavan ydin on uudeksi lukutaitotutkimukseksi nimetty suuntaus New Literacy Studies (Gee 1990; Street 1993; Collins 1995), joka kohdistaa huomion siihen, mitä lukutaidolla tehdään tai mihin sitä käytetään. Suuntauksen ydinkäsitteitä ovat lukutaitotapahtuma ja lukutaitokäytäntö, jotka painottavat tilannekohtaisuuden merkitystä lukutaidon tutkimisessa (Street 2001, 10-11; Unesco 2006a, 151). Etnografiset menetelmät ovat keskeisiä sosiokulttuurisessa lukutaitotutkimuksessa. Esimerkiksi Bartonin ja Hamiltonin (1998) Lancasteriin sijoittuva tutkimus käsittelee sitä, miten ihmiset käyttävät luku- ja kirjoitustaitoa arkielämänsä organisoinnissa ja paikallisyhteisön elämässä. Hare (2005) tarkastelee Kanadan alkuperäisväestön suhdetta lukutaitoon. Viimeaikaiset kehitysmaihin sijoittuvat tutkimukset ovat dokumentoineet sekä lukutaitoon että sen kulttuuriseen kontekstiin liittyviä moninaisuuksia, jotka eivät ole aiemmin saaneet tarpeeksi huomiota (ks. Street 2001; Olson \& Torrance 2001; Robinson-Pant 2004). 
Lukutaitoon liittyi aiemmin dualistisen ajattelu. Vastakkain asetettiin lukutaitoinen ja lukutaidoton, koulutettu ja kouluttamaton sekä moderni ja perinteinen. Samoin keskustelut sivistyksestä ja barbariasta sekä kirjallisesta ja suullisesta kulttuurista kytkeytyivät lukutaitoon. (Collins \& Blot 2003, 3-10.) Uusi lukutaitotutkimus -suuntaus on jatkanut tämän kahtia jaon aiemmin alkanutta purkamista. Viitekehys on puolustanut suullisen kulttuurin asemaa literacy-käsitteen yhteydessä. Unescokin (2006a, 149-152), joka aiemmin tukeutui tekstisidonnaiseen määritelmään, lukee nykyisin suulliset taidot osaksi literacy-käsitettä. Seuraava esimerkki osoittaa, miksi on ollut tarpeen rikastaa lukutaitokäsitystä. Street (1984) herkistyi lukutaidon tilannesidonnaisuudelle, kun hän teki antropologista tutkimusta Iranissa 1970-luvun alussa. Siellä oli vallitsevana maktab-lukutaito, joka perustui koraanin säkeiden ulkolukuun koraanikouluissa. Kaksijakoisen kansainvälisen lukutaitokriteerin mukaan ulkolukua osaavat oppilaat Iranissa olisivat luokittuneet lukutaidottomiksi, vaikka heillä oli huomattava suhde kirjalliseen ainekseen.

Uusi lukutaitotutkimus -koulukunnan tulkinta lukutaidosta korostaa kommunikaatiota. Suuntaukselle teksti on vain yksi kommunikaation muoto. Lukutaitotutkimuksessa on siis kaksi toisistaan poikkeavaa tulkintaa siitä, mikä on kirjallisen viestinnän lisäarvo todellisuuden rakentumiselle. Uusi lukutaitotutkimus -koulukunnan johtavan lukutaitotutkija Streetin (1995, 150-159) mukaan kieli ja käsitteet, ei siis lukutaitoisuus, rakentavat todellisuutta. Hänen tulkinnassaan kuvat, rituaalit ja tarinat abstrahoivat todellisuutta eli tekevät sitä samaa, mitä Ong (1982), Olson (1994) ja Goody (2000) puolestaan liittävät lukutaitoon ja kirjoitukseen.

\section{Sosiokulttuurisuus ja vähemmistöt}

Lukutaito on kielenkäytössä opittu kielen käytön metataito (Gee 1990, 149-154), jolla on yhteiskuntapoliittista merkitystä. Heath (1983) osoitti tämän, kun hän vertaili lukutaitoon ja kielenkäyttöön sosiaalistumista Lounais-Yhdysvalloissa kolmella asuinalueella. Yksi näistä oli valkoisen ja toinen mustan työväestön alue. Kolmannessa paikassa asui sekaisin sekä valkoista että mustaa keskiluokkaa. Heathin tutkimus toi esiin lukutaitoon liittyvää rasismia. Virallisten instituutioiden käytäntöjen kannalta kaikkien yhteisöjen tai kotien kielelliset käytännöt eivät nimittäin olleet yhtä arvokkaita, vaan mustien kulttuuris-kielellisiä vaikeuksia määriteltiin kouluissa tylymmin kuin valkoisten. Etnografinen tutkimus näytti sen, että lukutaito ei ole neutraali asia, vaan kielen oppimisen äärellä voidaan tuottaa ja uusintaa valtarakenteita. Yhdysvalloissa monikulttuurisuus tekee lukutaidosta tärkeän keinon, jolla voi rakentaa kulttuurista yhtenäisyyttä (Hirsch \& Kett \& Trefil 1987). Koska kulttuurinen moninaisuus on lisääntynyt Suomessa, Heathin tutkimusasetelmaa mukailemalla voisi tutkia, onko Suomen kouluissa syrjintää, joka liittyisi kielen osaamiseen.

Lukutaito ei kata suinkaan kaikkea olennaista kommunikaatiossa tai kielenkäytössä. Toisaalta vivahteikkainkaan suullinen viestintä ei saavuta kirjallisen viestinnän hyötyjä kuten tehokasta tiedonsiirtoa, tiedon varastointia ja analysointimahdollisuuksia. Näiden tiedonkäsittelyetujen vuoksi lukutaito tukee abstraktia käsitteen muodostusta. Kirjoittaminen tekee mahdolliseksi esittää itse luotuja ajatuskulkuja monenlaisille yleisöille ja myös itselle. Kirjoituksella on suuri merkitys modernisoituvan yhteiskunnan organisoimisen välineenä. (Ong 1982; Goody 2000; Olson \& Torrance 2001.)

Maailman kielellinen moninaisuus muodostaa yhden koulutuksen ja lukutaidon suurimmista haasteista. Esimerkiksi Aasiassa on yli 2000 kieltä, mutta niistä vain 45 on virallisia kieliä. Kuitenkin lähes kaikki opetus annetaan virallisilla kielillä. Tämä tarkoittaa, että suuren osan maailman väestöä täytyy opetella uusi kieli pystyäkseen käymään koulua, vaikka tiedetään, että oppiminen on tehokkainta omalla äidinkielellä. (Unesco 2007.) Esimerkiksi Saharan eteläpuolisessa Afrikassa vain 13 prosenttia oppilaista voi käydä peruskoulua äidinkielellään. Aasiassa puolestaan kaksi kolmesta lapsesta voi opiskella äidinkielellään. (Undp 2004, 34.) Puolet maailman koulupudokkaista on niitä, joiden äidinkielellä ei saa kouluopetusta (World Bank 2005, 1). Näin kansalliset kieli- ja koulutuspolitiikat ratkaisevat monien kielivähemmistöön kuuluvien kohtaloita yksilöinä ja ryhminä. (Unesco 2006a, 200-205; 2007, 1-9).

Monikulttuurisessa maailmassa lukutaito liittyy poliittiseen kamppailuun oikeudesta omaan kulttuuriin ja identiteettiin. Collins ja Blot (2003, 99167) käsittelevät kolonialismia ja esimerkiksi Amerikoissa alkuperäisväestön identiteettiin kohdistettua vallankäyttöä. Sosiokulttuurinen näkökulma lukutaitotutkimukseen on ollut valtakriittinen. Etnografiseen tutkimusotteeseen liittyy kuitenkin vaara korostaa liikaa paikallisuutta ja jättää huomiotta sellaisia ulkoisia voimia kuten kolonialismi 
tai globalisaatio (Unesco 2006a, 151). Sosiokulttuurisen näkökulman kautta on huomattu, että lukutaito voi olla sekä vallankäytön että vapauttamisen väline aivan kuten Raassina (1990, 93-103) paikantaa keskeisen jännitteen. Tämän dilemman analysoinnissa tarvitaan lisää kriittistä tutkimusta.

\section{Lukutaito informaatioyhteiskunnassa}

Kun teollinen yhteiskunta on muuttunut informaatioyhteiskunnaksi, tiedon käsittelyyn viittaava lukutaito on muodostunut yleiskäsitteeksi. Nykyisin jopa tunteita ja moraalia halutaan tarkastella lukutaitoina (Collins \& Blot 2003, 1-3). Pirjo Linnakylä (1991) pohti kaukonäköisesti sitä, miten lukutaidon käsite rapautuu: ”Miksi emme voisi puhua kuvien tulkinnasta tai tietotekniikan käytöstä, ympäristön suojelusta, kulttuuri-, moraali- ja arvokasvatuksesta?” Janne Seppänen $(2002,17)$ toteaa samasta ilmiöstä: Lukutaito on metaforisoitunut, koska sillä voidaan viitata minkä tahansa osaamisen hallintaan. Informaatioyhteiskunnassa on noussut esiin uusia lukutaitojohdannaisia käsitteitä, joista tärkeimmät ovat informaatiolukutaito, digitaalinen lukutaito ja medialukutaito.

Medialukutaidon edelläkävijä Marshall McLuhan (1968) pohti, mitä vaikutuksia on sillä, että ihmisillä on käytössään aiempaa enemmän uusia todellisuuden kokemisen ja kommunikoimisen välineitä. Medialukutaito on nykyisin suosiossa olevan oppiaineen, mediakasvatuksen, keskeinen näkökulma. Medialukutaito on perspektiivi, jolla tulkitsemme kohtaamiamme median välittämiä viestejä (Potter 2001, 4). Digitaalisen ajan lukutaitoon yhdistyy informaatiokanavien runsaus ja yhtäaikaisuus. Teksti täydentyy sähköisillä viesteillä, televisiokuvalla ja internetillä. (Withrow 2004, 2932.) Medialukutaito yhdistetään juuri sähköiseen viestintään, jonka myötä kommunikaatio on yhä monimuotoisempaa, nopeampaa ja usein sen interaktiivisuus lisääntyy. Reijo Kupiainen (2006) kytkee medialukutaidon ja digitaaliset keksinnöt kansalaistoiminnan ja osallisuuden uusiin mahdollisuuksiin.

Tietoon perustuvassa yhteiskunnassa on käynnissä siirtymä kerrotusta tarinasta näkemisessä välittyvään viestiin (Kress 2003, 1-6; 172-175). Kuvaruutu on korvaamassa kirjan yhtenä keskeisenä kommunikaatiovälineenä. Medialukutaidon keskeisen osan muodostaa visuaalinen lukutaito, joka on ”kyky ymmärtää visuaalisten järjestysten kulttuurisia merkityksiä”. Kuvanlukutaito on puolestaan osa visuaalista lukutaitoa. (Seppänen 2002, 19, 148-150.) Kuva on ollut tärkeä väline opetuksessa jo ennen lukutaidon yleistymistä. Tästä kertovat mm. kirkkojen kuvataulut.

Bawden (2001) tarkastelee informaatiolukutaitoa ja digitaalista lukutaitoa. Hän viittaa informaatiolukutaidolla tietoyhteiskunnan kykyperusteisia taitoja kuten tietokonelukutaitoa, computer literacy, yleisluontoisempaan taitoon ja ymmärrykseen käyttää tietoa. Gilster $(1997,1)$ puolestaan kytkee digitaalisen lukutaidon käsitteen tietoon, joka tulee tietokoneen välityksellä. Lankshearille ja Knobelille (2003, 155-206) digitaaliset lukutaidot ovat uusia kommunikaatiovälineitä ja -muotoja, joista he käyttävät yleisnimenä käsitettä literacy. Heidän tapansa käyttää lukutaitokäsitettä poikkeaa aiemmasta ja synnyttää sekaannusta. Literacyn sijaan Lankshearille ja Knobelille olisi sopinut paremmin käsitteeksi kommunikaatiokäytäntö, jollainen on esimerkiksi nettihuutokauppaa ja siihen liittyvää asiakasyhteisön palautejärjestelmä.

Vaikka internetiin liittyvät keksinnöt ovat joiltain osin aivan uusia kommunikaatiokäytäntöjä, niin useimpien digitaalihyödykkeiden kuten ohjelmien tai laitteiden käyttäminen edellyttää lukuja kirjoitustaitoa. Toisaalta nykyisin on mahdollista siirtää, säilyttää ja analysoida informaatiota ilman lukutaitoa esim. videomateriaalin avulla, mutta tällöinkin tarvitaan teknistä osaamista ja medialukutaitoa.

Informaatioyhteiskunnassa on kiinnostavaa, että uudessa ajassa tarpeellisia osaamisia nimitetään lukutaidoksi. Kuitenkaan se, että henkilöllä on "oiva tunnelukutaito” ja vielä elektronisten välineiden käyttäjänä "auttava digitaalinen lukutaito", ei tee esimerkiksi maahanmuuttajasta tai kehitysmaan asukkaasta luku- ja kirjoitustaitoista. On tärkeää muistaa, että lukutaitoa tarvitaan myös perinteisessä merkityksessä.

Informaatioyhteiskunnassa lukutaitoon liittyy paljon kiinnostavia tutkimusaiheita. Esimerkiksi joissakin maissa vieraskielisten elokuvien tai sarjojen päälle puhutaan katsojien äidinkielellä. Suomessa käytetään tekstikäännöstä. Mikä on "dubbauksen” vaikutus lukutaitoon ja kielitaitoon? Maahanmuuttajat tulevat tänne yleensä Suomea vähemmän kirjallisesti painottuneista kulttuureista, siksi heidän lukutaitoonsa olisi hyvä kohdistaa erityistä huomiota. Digitaalisen lukutaidon yhteydessä on kiinnostavaa se, kuinka YK onnistuu aloitteessaan viedä tietoyhteiskunnan elementtejä 
kehitysmaihin (ks. Uneca 2006). Mikä osa digitaalisista hyödykkeistä - esineistä ja käytännöistä on sellaisia, joita lukutaidottomatkin voivat käyttää? Minkä tasoista luku-, kirjoitus- ja laskutaitoa afrikkalaisen tietoyhteiskunnan luominen edellyttää? Entä minkälainen on vähäisen lukutaidon informaatioyhteiskunta?

\section{Lukutaitotutkimuksen kartat}

Tämä artikkeli tarkastelee kuutta lukutaidontutkimukseen liittyvää käsitettä. Kuvio 1 esittää näitä viitekehyksiä luokiteltuna kahdelle ulottuvuudelle. Tietoyhteiskunnan lukutaitojen osalta kuviossa on kaksi käsitettä. Laatikon koolla kuviossa ei ole yhteyttä kunkin viitekehyksen merkittävyyteen. Sen sijaan sijainti kaaviossa ratkaisee. Tarkasteltavat käsitteet on sijoitettu vaaka-akselilla sen mukaan, korostuuko lukutaidon määritelmissä tekstinhallinta vai kommunikaatio. Pystyakselin ulottuvuus kertoo siitä, kuinka paljon kulttuurisia erovaisuuksia painotetaan.

Varhaisemmat lukutaitotutkimuksen viitekehykset pitävät lukutaitoa universaalimpana kuin myöhemmät käsitystavat. Esimerkiksi lukutaitoisuusaste on tapa määritellä lukutaito tekstin hallinnan taidoiksi, jotka ovat kaikkialla samoja. Myös lukutaidon osaamistasojen pohjana on kulttuurineut- raalit tekstin hallintaan liittyvät taidot. Kuvion 1 ulottuvuudet ilmentävät kahta kansainvälisen vertailevan lukutaitotutkimuksen keskeisintä haastetta: Mikä on yhteistä kaikille kulttuureille? Ja kuinka tulisi painottaa kommunikaatiota suhteessa tekstin hallintaan? Kansainväliset vertailut ovat omaksuneet parhaita puolia esitellyistä lukutaitotutkimuksen käsitteistä. Tästä muodostuu niiden validius eli pätevyys tulkita maailman lukutaitoa.

Freireläinen lukutaitokäsitys on korostanut lukutaidon oppimista niin, että opittavat käsitteet nousevat oppilaiden oman elämän kontekstista. Samoin funktionaaliseen lukutaitoon ja sosiokulttuuriseen lähestymistapaan on sisältynyt ajatus huomioida konteksti. Silti funktionaalinen suuntaus ei ole samalla tavoin irtaantunut tekstisidonnaisuudesta kuin sosiokulttuurinen lähestymistapa, joka usein määrittelee lukutaidon kommunikaation taitoina. Samoin informaatioyhteiskunnan lukutaitokäsitykset viittaavat lukutaidolla useammin kommunikaatioon kuin tekstin hallintaan.

Kuvio 2 perustuu lukutaitotutkimuksessa paljon siteerattujen teosten läpikäyntiin. Se on silti suuntaa-antava. Kuvio 2 osoittaa sen, mitkä lukutaidon tutkimussuuntaukset ovat olleet vallalla eri aikoina. Lukutaitoaste oli ainoa tapa tarkastella lukutaitoa 1950-luvun lopulle saakka. Lukutaidontutkimuksen käsitteet on asetettu kuvioon 2 aika-

Kuvio 1. Lukutaitotutkimuksen käsitteet

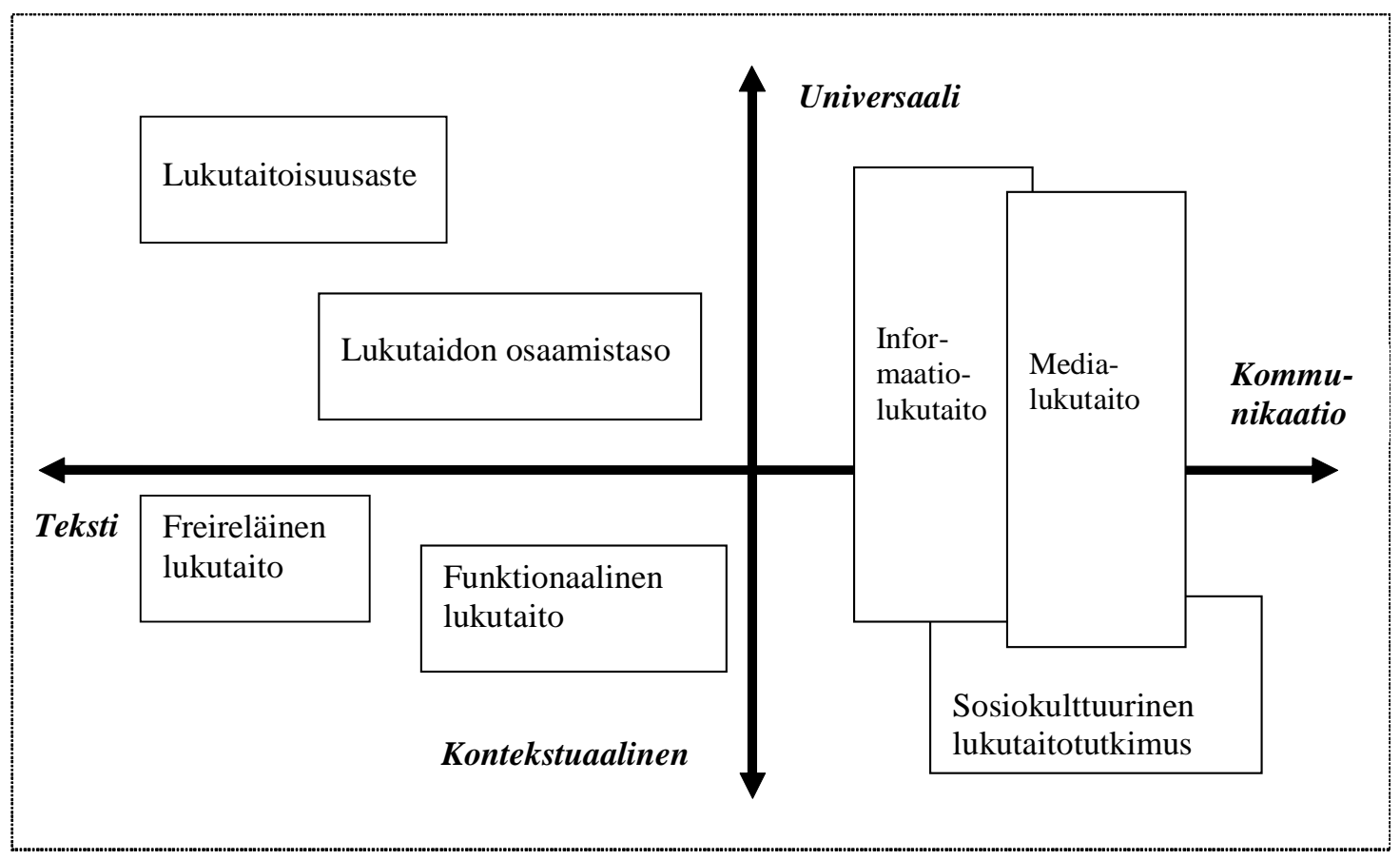


Kuvio 2. Lukutaitotutkimuksen käsitteiden asema ja ajoitus

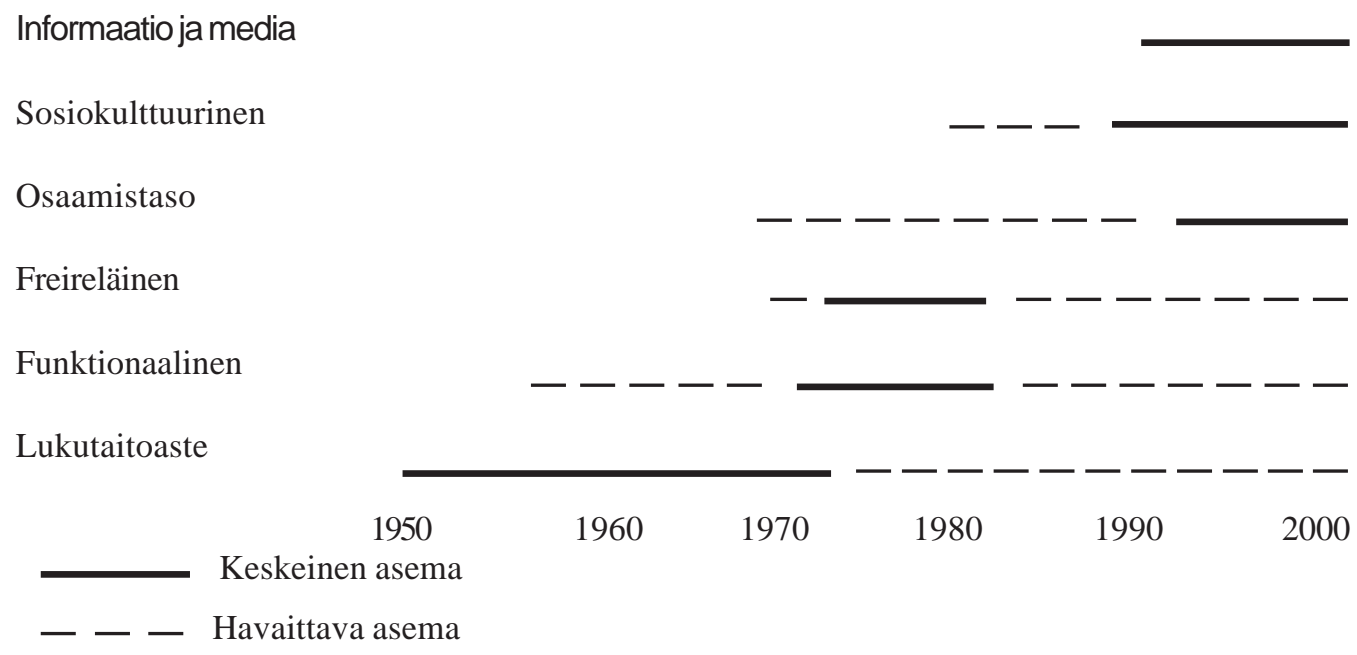

järjestykseen. Nykyisin lukutaitoisuusasteen rinnalla on useita tapoja lähestyä lukutaitoa. Lukutaidon osaamistasojen vertailu on korvaamassa lukutaitoisuusasteen tieteellisesti pätevänä tapana tarkastella lukutaitoa. Osaamistasoa voidaan arvioida yksilö-, ryhmä- ja maatasoilla. Unescon (2006b) kansainvälinen arviointihanke (LAMP) tavoittelee luotettavan ja yhteismitallisen käsityksen muodostamista lukutaidosta ja sen osaamistasoista.

Funktionaalisuus on tarkoittanut lukutaidon merkitystä suhteessa muihin tavoiteltaviin asioihin kuten taloudelliseen tai kansalliseen kehitykseen tai informaatioyhteiskunnassa mukana pysymiseen. Funktionaalinen lukutaito on käyttökelpoinen käsite vaikkapa oppimisvaikeuksien ja maahanmuuttajien kotouttamisen yhteydessä. Freireläisessä käsityksessä lukutaito on osa lukutaidottomien kamppailua asemansa parantamiseksi. Freireläisyys voi toimia nykypäivän näkökulmana media- ja informaatiolukutaitojen oppimisessa.

Sosiokulttuurinen lukutaitotutkimus ja etnografisten menetelmien soveltaminen lukutaitoon alkoi laajassa mitassa 1980-luvulla. Tuolloin tuli tärkeäksi kiinnittää huomion kontekstiin, tilanteeseen ja yhteisöön, joissa lukutaitoa tarkastellaan. Sosiokulttuurinen tutkimus on myös tarkentanut suullisen ja kirjallisen kulttuurin käsitteitä suhteessa lukutaitoon. Literacy-käsitettä käytetään myös laajentuneessa merkityksessä, koska nykyisin lukutaito voidaan liittää lähes minkä tahansa systemaattisen tietomuodostuman hallintaan (Collins \&
Blot 2003, 1-3). Tätä ymmärrystapaa ei ole kuviossa 1.

Tietoyhteiskunnan yhteydessä lukutaito liitetään lukemisen ja kirjoittamisen lisäksi uusien kommunikaation välineiden ja taitojen määreeksi. Näin on esimerkiksi medialukutaidon ja informaatiolukutaidon osalta. Koska kuva on nousemassa tekstin rinnalle merkitysten välittäjänä, on kuviakin opittava lukemaan. Sekä teksti että kuva ovat yhä useammin sähköisessä muodossa. Digitaalinen lukutaito viittaa lisääntyvään sähköisen median käyttöön ja uusiin kommunikaatiomuotoihin, jotka vaikuttavat lukutaidon tarpeeseen ja sisältöön.

Tämän artikkelin tulos on tiivistetty yllä oleviin kuvioihin. Sen avulla lukutaidosta kiinnostunut henkilö voi löytää oman kysymyksensä kannalta mielekkään lukutaidon ymmärrystavan. Ylipäänsä lukutaidon edistäminen voi olla mitä tehokkainta kehitysapua. Suomalainen koulutusosaaminen voisi palvella nykyistä enemmän globaalia sosiaalista kehitystä. Suomi voisi rahoittaa lukutaidon dokumentointiin liittyvää LAMP-hanketta joidenkin kehitysmaiden puolesta. On myös järkevää tukea moninaista kansalaisyhteiskunnan aktivoimista ja organisoitumista. Näin syntyy käyttöä lukutaidolle ja tarvetta oppia lukutaitoa (ks. Auerbach 2005). Samoin maahanmuuttajien kotouttamisessa lukutaidon ja kansalaistoiminnan yhdistäminen voi olla viisasta. Tässä ajassa tiedon käyttötaito on menestystekijä ja sen puuttuminen syrjäytymisriski.

Kehitysmaiden lukutaitoon liittyviä hyviä tutkimuskysymyksiä on runsaasti. Voivatko kouluja 
käymättömät ihmiset siirtyä suoraan suullisesta kulttuurista kannettavien tietokoneiden käyttöön? Voiko osa esimerkiksi etelän metropolien kaupunkilaisista toimia pelkästään kuvallisen ja puhutun informaation varassa? Näihin kysymyksiin vastattaessa on tärkeä ymmärtää lukutaidon moninaisuutta. Yhtäältä eri lukutaitokäsitykset auttavat vastaamaan erilaisiin kysymyksiin. Toisaalta useamman lähestymistavan käyttö voi tuoda tulkintaan suhteellisuutta.

Joka tapauksessa väestön perinteiset luku- ja kirjoitustaidot sekä informaatioyhteiskunnan lukutaidot vaikuttavat siihen, minkälaiset toiminnat ovat mahdollisia, sekä siihen, kuinka kansalaiset voivat osallistua julkisiin keskusteluihin ja itseään koskevista asioista päättämiseen. Globaalilta kannalta katsoen pitkä historia on suullisen kulttuurin. Lähimenneisyys ja nykyisyys korostavat kirjallisen kulttuurin ja lukutaidon arvoa. Onko tulevaisuudessa paluu suulliseen kulttuuriin? Ei vanhaan paikalliseen kulttuuriin vaan sellaiseen suulliseen kulttuuriin, jota maantieteellisiä rajoja ylittävä sähköinen kuvallinen viestintä värittää. Vai tuleeko lukutaito säilyttämään keskeisen paikkansa? Vaihtoehdot eivät ole yhdentekeviä esimerkiksi globaalin hallinnan kannalta.

\section{Kirjallisuus}

Arnove, R. F. \& Graff, H. J. (toim.) (1987). National literacy campaigns. Historical and comparative perspectives. Plenum Press.

Auerbach, E. (2005). Connecting the local and the global: A pedagogy of not-literacy. Teoksessa Andersson, J. \& Kendrick, M. \& Rogers, T. \& Smythe, S. (toim.) Portraits of literacy across families, community and school. Intersections and tensions. Lawrence Erlbaum Associates, 363-379.

Barton, D. \& Hamilton, M. (1998). Local literacies. Reading and writing in one community. Routledge.

Bawden, D. (2001). Information and digital literacies: A review of concepts. Journal of Documentation, Vol. 57 (2), 218-259.

Burchfield, S. \& Hua, H. \& Baral, D. \& Rocha, V. (2002). A longitudinal study of the effect of integrated literacy and basic education programs on the participation of woman in social and economic development in Nepal. US Agency for International Development, Bos- ton. http://pdf.usaid.gov/pdf_docs/PNACR 861.pdf (1.3.2008)

Cipolla, C. (1969). Literacy and development in the west. Penguin.

Collins, J. (1995). Literacy and literacies. Annual Review of Anthropology, Vol. 24, 75-93.

Collins, J. \& Blot, R. K. (2003). Literacy and literacies. Texts, power and identity. Studies in the social and cultural foundations of language. Cambridge University Press.

Coulombe, S. \& Tremblay J. F. \& Marchand S. (2004). Literacy scores, human capital, and growht across fourteen OECD countries. Statistics Canada. http://www.statcan.ca/english/ research/89-552-MIE/89-552-MIE2004011.pdf (1.3.2008)

Freire, P. (1972). Pedagogy of the oppressed. Penguin. Suom. (2005) Sorrettujen pedagogiikka. Vastapaino.

Freire, P. (1987). Education for critical consciousness. Continuum.

Freire, P. (2001). Pedagogy of freedom. Ethics, democracy and civic courage. Rowman \& Littlefield.

Freire, P. \& Macado, D. (1987). Literacy. Reading the word and the world. Bergin \& Garvey.

Gee, J. P. (1990). Social linguistics and literacies. Ideology in discourse. Falmer Press.

Gilster, P. (1997). Digital literacy. John Wiley \& Sons.

Goody, J. (1968). Introduction. Teoksessa Goody, J. (toim.) Literacy in the traditional societies. Cambridge University Press, 1-26.

Goody, J. (2000). The Power of the written tradition. Smithsonian Institution Press,

Graff, H. J. (1979). The literacy myth. Literacy and social structure in the nineteen-century city. Academic Press.

Graff, H. J. (toim.) (1981). Literacy and social development in the West. Cambridge University Press.

Gran, G. (1983). Development by people. Citizen construction of a just world. Praeger.

Gray, W. S. (1956). The teaching of reading and writing. Unesco.

Hamilton, M. \& Barton, D. (2000). The international adult literacy survey: What does it really measure? International Journal of Educati- 
on Vol. 46 (5), 377-389.

Hannula, A. (2000). Tiedostaminen ja muutos Paolo Freiren ajattelussa. Systemaattinen analyysi sorrettujen pedagogiikasta. Helsingin yliopiston kasvatustieteen laitoksen julkaisuja 167. http://ethesis.helsinki.fi/julkaisut/ kas/kasva/vk/hannula/tiedosta.pdf (1.3.2008)

Hannum, E. \& Buchman, C. (2003). The Consequences of global education expansion: Social science perspectives. American Academy of Arts and Scienses. http://www.amacad.org/ publications/monographs/Ubase.pdf (1.3.2008)

Hare, J. (2005). To "Know Papers”: Aboriginal perspectives on literacy. Teoksessa Andersson, J. \& Kendrick, M. \& Rogers, T. \& Smythe, S. (toim.). Portraits of literacy across families, community and school. Intersections and tensions. Lawrence Erlbaum Associates, 243-263.

Heath, B. S. (1983). Ways with words. Language, life, and work in communities and classrooms. Cambridge University Press.

Hirsch, E. D. Jr. \& Kett, J. F. \& Trefil, J. S. (1987). Cultural literacy: What every American needs to know. Houghton Mifflin.

Hoggart, R. (1957). The uses of literacy. Penguin.

Kiilakoski, T. \& Tomperi, T. \& Vuorikoski, M. (toim.) (2005). Kenen kasvatus? Kriittinen pedagogiikka ja toisinkasvatuksen mahdollisuus. Vastapaino.

Kress, G. (2003). Literacy in the new media age. Routledge.

Kupiainen, R. (2006). Yhteistoiminnallinen medialukutaito. Aikuiskasvatus, Vol. 26 (3)

Lankshear, C. \& Knobel, M. (2003). New literacies: changing knowledge and glassroom learning. Open University Press.

LeVine, R. A. \& LeVine, S. \& Rowe, M. L. \& Schnell-Anzola, B. (2004). Maternal literacy and health behaviour: a Nepalese case study. Social Science \& Medicine. Vol. 58 (4), 863877.

Linnakylä, P. (1991). Toimiva lukutaito - valtaa ja vapautta. Teoksessa Hiltunen, M. \& Toukonen, M. L. (toim.) Toimiva lukutaito. Seminaari Tampereella 12.-13.11.1990. Suomen Unesco-toimikunta.
Linnakylä, P. \& Malin, A. \& Blomqvist, I. \& Sulkunen, S. (2000). Lukutaito työssä ja arjessa. Aikuisten kansainvälinen lukutaitotutkimus Suomessa. Koulutuksen tutkimuslaitos.

Lytle, S. \& Wolfe, M. (1989). Contrasting Perspectives on Adult Education. Teoksessa Adult literacy education: Program evaluation and assessment. Columbus ERIC, 5-17.

McLuhan, Marshall (1964). Understanding media. The extensions of man. Signet. Suom. (1968) Ihmisen uudet ulottuvuudet. WSOY.

Murray, S. T. \& Clermont, Y \& Binkley, M. (2005). Measuring adult literacy and life skills: New frameworks for assesment. Minister of Industry Canada. http://www.unesco bkk. org/fileadmin/user_upload/aims/literacy/ FrameworksAssessment_Scott.pdf (1.3.2008)

OECD \& Statistics Canada. (2000). Literacy in the information age. Final report of the International Adult Literacy Survey. OECD Publications.

OECD. (2008). PISA. http://www.pisa.oecd.org/ pages/0,2987,en_32252351_32235731_1_1_1 _1_1,00.html (1.3.2008)

Olson, D. R. (1994). The world on paper. The conceptual and cognitive implications of writing and reading. Cambridge University Press.

Olson, D. R. \& Torrance, N. (toim.) (2001). The making of literate societies. Blackwell Publishers.

Ong, W. J. (1982). Orality and literacy. The technologizing of the word. Routledge.

Paananen, S. (2006). Dysleksia, identiteetti ja biografinen oppiminen. Dysleksia aikuisen elämänkerronnassa. Acta Universitatis Lapponiensis 107.

Perkiö, M. (2007). Lukutaito keinona kehitysmaiden yhteiskuntapolitiikassa. Janus, Vol. 15 (4), 367-375.

Potter, W. J. (2001). Media literacy. Sage.

Raassina, A. (1990). Lukutaito ja kehitysstrategiat. Kolme vuosikymmentä Unescon lukutaitopolitiikkaa. Jyväskylän yliopisto Nykykulttuurin tutkimusyksikkö.

Robinson-Pant, A. (toim.) (2004). Women, literacy and development. Alternative perspectives. Routledge.

Ross, K. (2006). Status of women in highly lite- 
rate societies: the case of Kerala and Finland. Literacy. Vol. 40 (3), 171-178.

Schaffner, J. (2005). Measuring literacy in developing country household surveys: Issues and evidence. Backround paper for Education for All monitoring report 2006. http:// unesdoc.unesco.org/images/0014/001462/ 146285e.pdf (1.3.2008)

Schnell-Anzola, B. \& Rowe, M. L. \& LeVine, R.A. (2005). Literacy as a pathway between schooling and health-related communication skills: a study of Venezuelan mothers. International Journal of Educational Development. Vol. 25 (1), 19-37.

Seppänen, J. (2002). Katseen voima. Kohti visuaalista lukutaitoa. Vastapaino.

Statistics Canada. (2005). Learning a living: First results of the adult literacy and life skills survey. http://www.statcan.ca/english/ freepub/89-603-XIE/2005001/pdf.htm(1.3.2008)

Street, B. V. (1984). Literacy in theory and practice. Cambridge University Press.

Street, B. V. (1993). Cross-cultural approaches to literacy. Cambridge University Press.

Street, B. V. (1995). Social literacies. Critical approaches to literacy in development, ethnography and education. Longman.

Street, B. V. (2001). Introduction. Teoksessa Street B. V. (toim.) Literacy and development. ethnographic perspectives. Routledge, 1-18.

Suoranta, J. (2005). Radikaali kasvatus. Kohti kasvatuksen poliittista sosiologiaa. Gaudeamus.

Takala, T. (2001). Koulutus kaikille - tavoitteet ja kehitysmaiden todellisuus. Tmi DevEd Consulting.

Thorndike, R. L. (1973). Reading comprehension education in fifteen countries. Almqvist \& Wiksell.

Undp. (2004). Human development report. Human liberty in today's diverse world. http:// hdr.undp.org/en/media/hdr04_complete.pdf (1.3.2008)

Uneca. (2006). African information society initiative (AISI). An action framework to build Africa's information and communication infrastructure. United Nation Economic Commission for Africa. http://www.uneca.org/aisi/ (1.3.2008)
Unesco. (1957). World llliteracy at mid-century.

Unesco. (1973). Practical guide to functional literacy.

Unesco. (2005). Education for All global monitoring report. The quality imperative. Part II. Why literacy matters. http://portal.unesco. org/education/en/ev.php-URL_ID=43048\& URL_DO=DO_TOPIC\&URL_SECTION $=201 . h \mathrm{tml}$ (1.3.2008)

Unesco (2006a). Education for all global monitoring report. Literacy for life. http://portal. unesco.org/\&URL_DO=DO_TOPIC\&URL_ SECTION =201.html (1.3.2008)

Unesco. (2006b). Literacy assessment and monitoring programme (LAMP). http://www.uis.

unesco.org/TEMPLATE/pdf/LAMP/

LAMP_EN_2005.pdf (1.3.2008)

Unesco. (2007). Promoting literacy in multilingual world. http://www2.unescobkk.org/elib/ publications/100/multilingual.pdf (1.3.2008)

Verhoeven, L. (1994). Modelling and promoting functional literacy. Teoksessa Verhoeven, L. (toim.) Functional literacy. Theoretical issues and educational implications. John Benjamins, 3-34.

Withrow, F. B. (2004). Literacy in the digital age. Reading, writing, viewing and computing. Lanham.

World Bank. (2005). In their language ... Education for All. http:// siteresources.worldbank.org/EDUCATION/ Resources/Education-Notes/

EdNotes_Lang_of_Instruct.pdf (1.3.2008)

Kiitän Jorma Sipilää artikkelin useista perusteellisista kommentoinneista. Kiitän rakentavasta palautteesta ja ideoista Anneli Anttosta, Matti Alestaloa, Tuomas Takalaa ja Eriikka Oinosta. Aikuiskasvatus-lehden nimettömien arvioitsijoiden huomiot ovat parantaneet tekstiä. Kiitos niistä. Artikkeli on osa väitöskirjatutkimustani, joka käsittelee lukutaidon ja sosiaalisen kehityksen suhdetta. Tutkimusta on rahoittanut Suomen kulttuurirahasto sekä tutkimuksen alkuvaiheessa Tampereen yliopisto.

Artikkeli saapui toimitukseen 19.4.2007. Se hyväksyttiin julkaistavaksi toimituskunnan kokouksessa 10.3.2008. 